\title{
UJI AKTIVITAS ANTIOKSIDAN EKSTRAK ALGA COKLAT Sargassum polycystum DAN Turbinaria deccurens ASAL PULAU DUTUNGAN SULAWESI SELATAN TERHADAP RADIKAL DPPH
}

\author{
Fitriyanti Jumaetri Sami ${ }^{* 1,2}$, Nunuk Hariani Soekamto ${ }^{1}$, Firdaus ${ }^{1}$, Jalifah Latip ${ }^{3}$ \\ ${ }^{1}$ Jurusan Kimia Universitas Hasanuddin Makassar \\ ${ }^{2}$ Sekolah Tinggi Ilmu Farmasi Makassar \\ ${ }^{3}$ School of Chemical Sciences and Food Technology, The National University of Malaysia \\ *email: fitriyantijumaetri_sami@yahoo.com
}

Received 27 Desember 2018

Accepted 28 Juni 2019

\begin{abstract}
Abstrak
Penelitian ini bertujuan untuk menyelidiki aktivitas antioksidan dari ekstrak metanol, etil asetat, dan n-heksana dari alga coklat spesies Sargassum polycystum dan Turbinaria decurrens. Ekstraksi sampel dengan metode maserasi, uji aktivitas antioksidan menggunakan metode perendaman DPPH (1,1-Diphenyl-2-picryl Hidrazil) diukur penyerapan pada panjang gelombang $515 \mathrm{~nm}$ dan dibandingkan dengan kontrol antioksidan vitamin C. Hasil penelitian menunjukkan bahwa aktivitas antioksidan dari ekstrak metanol, etil asetat, n-heksana dari $S$. polycystum memiliki aktivitas antioksidan kategori rendah dengan nilai $\mathrm{IC}_{50} 340,06,180,54$, dan $502,25 \mathrm{mg} / \mathrm{mL}$. Ekstrak metanol, etil asetat, n-heksana dari $T$. deccurens memiliki aktivitas antioksidan kategori rendah dengan nilai $\mathrm{IC}_{50} 491,02$, 411,80, dan 502,7 mg/mL. Potensi ini lebih rendah dari nilai $\mathrm{IC}_{50}$ vitamin $\mathrm{C}$ sebesar 1,72 $\mathrm{mg} / \mathrm{mL}$.
\end{abstract}

Katakunci: Antioksidan, S. polycystum, T. deccurens, Pulau Dutungan

\begin{abstract}
The research was aimed to investigate antioxidant activites of methanol, ethyl acetate, and n-hexane extract of brown algae Sargassum polycystum and Turbinaria decurrens spesies. Extraction of samples by maceration method, antioxidant activity assay using the immersion method of DPPH (1,1-Diphenyl-2-picryl Hidrazil) measured absorption at a wavelength of $515 \mathrm{~nm}$ and compared with the control of antioxidant vitamin $\mathrm{C}$. The results showed that antioxidant activity of the methanol, ethyl acetate, n-hexane extract of $S$. polycystum have low category antioxidant activity with the value $\mathrm{IC}_{50} 340,06,180,54$, and $502,25 \mathrm{mg} / \mathrm{mL}$. Methanol, ethyl acetate, n-hexane extracts of T. deccurens have low category antioxidant activity with value $\mathrm{IC}_{50} 491,02,411,80$, and $502,7 \mathrm{mg} / \mathrm{mL}$. This potential is lower than vitamin $\mathrm{C}_{\mathrm{IC}}$ value of $1,72 \mathrm{mg} / \mathrm{mL}$.
\end{abstract}

Keywords: Antioxidant, S. polycystum, T. deccurens, Dutungan Island

\section{Pendahuluan}

Indonesia memiliki keanekaragaman hayati laut yang cukup besar, pantai Indonesia mempunyai potensi alga yang cukup tinggi (Bengen, 2001). Phaeophyceaea merupakan kelompok alga coklat yang banyak tersebar di wilayah Indonesia. Menurut Permana (2008), pemanfaatan alga coklat dalam bidang industri diantaranya untuk industri makanan, minuman, kosmetik, kertas, 
detergen, cat, tekstil, dan obat-obatan. Turbinaria deccurens dan Sargassum polycystum merupakan jenis alga coklat yang belum dimanfaatkan maupun dibudidayakan. Oleh karena itu perlu dilakukan penelitian mengenai kandungan senyawa bioaktif terutama yang dapat dijadikan sebagai obat.

Phaeophyceae menunjukkan aktivitas antioksidan tertinggi di antara Rhodophyceae dan Chlorophyceae (Yangthong et al., 2009; Kelman et al., 2012). Phaeophyceae di daerah tropis memproduksi metabolit sekunder lebih baik sebagai suatu sistem proteksi terhadap radiasi sinar UV (Ultra Violet). Senyawa fenol dan turunannya diduga menjadi komponen utama senyawa antioksidan yang dihasilkan oleh Phaeophyceae (Budhiyanti et al., 2012). Proses ekstraksi dapat menggunakan tiga jenis pelarut dengan tingkat kepolaran yang berbeda, yaitu n-heksana (nonpolar), etil asetat (semipolar), dan etanol/metanol (polar). Perbedaan jenis pelarut ini akan mempengaruhi karakteristik dari senyawa bioaktif yang terdapat pada $S$. polycystum dan $T$. deccurens yang dimungkinkan memiliki aktivitas sebagai antioksidan.

Penelitian ini bertujuan untuk menguji aktivitas antioksidan dan skrining fitokimia pada ekstrak $S$. polycystum dan $T$. deccurens. Selanjutnya, data hasil aktivitas antioksidan dan skrining fitokimia dari $S$. polycystum dan $T$. deccurens tersebut dapat memberikan informasi dalam rangka pemanfaatan alga coklat.

\section{Metode Penelitian}

Alat dan bahan

Alat-alat yang digunakan dalam penelitian ini antara lain seperangkat alat gelas laboratorium, neraca analitik, rotary evaporator, dan spektrofotometer UV VIS.

Sampel yang digunakan dalam penelitian ini adalah alga coklat $S$. polycystum dan $T$. deccurens yang diperoleh dari pulau Dutungan Kabupaten
Barru Sulawesi Selatan. Bahan-bahan yang digunakan dalam penelitian ini yaitu metanol, etil asetat, n-Heksan, DPPH, $\mathrm{HCl}$ $2 \%, \mathrm{H}_{2} \mathrm{SO}_{4}$ pekat, asam asetat anhidrida, $\mathrm{FeCl}_{3} 1 \%$, pereaksi Meyer, Dragendorff, Wagner, dan serbuk logam Mg.

\section{Preparasi Sampel}

Alga coklat $S$. polycystum dan $T$. deccurens dibersihkan dari kotoran yang menempel dengan air laut, kemudian dicuci dengan air mengalir. Sampel selanjutnya dikeringkan pada oven simplisia pada suhu $38^{\circ} \mathrm{C}$ selama 48 jam, dan dihaluskan menggunakan blender hingga menjadi serbuk.

\section{Ekstraksi}

Ekstraksi dilakukan dengan cara maserasi bertingkat menggunakan nheksan, etil asetat, dan methanol. Serbuk alga $S$. polycystum dan $T$. Deccurens dimaserasi dengan pelarut n-heksan selama 3 × 24 jam, kemudian disaring. Residu dimaserasi kembali selama 24 jam dan disaring, lalu filtrat dipekatkan menggunakan rotary evaporator sehingga diperoleh ekstrak n-heksan. Residu diekstrak kembali berturut-turut dengan etil asetat dan metanol dengan cara yang sama.

\section{Uji Aktivitas Antioksidan}

a. Pembuatan Larutan DPPH (Molyneux, 2004)

DPPH ditimbang sebanyak 0,01577 g, dilarutkan dengan etanol, dicukupkan volumenya dengan metanol p.a hingga 100 $\mathrm{mL}$ dalam labu ukur.

b. Pengukuran serapan larutan blanko $D P P H$

Larutan DPPH dipipet sebanyak $1 \mathrm{~mL}$ dan dicukupkan volumenya sampai $5 \mathrm{~mL}$ dengan metanol p.a dalam labu ukur. Larutan ini kemudian diukur absorbansinya dengan Spektrofotometer UV-Vis pada panjang gelombang $515 \mathrm{~nm}$. c. Pengukuran aktivitas pengikatan $D P P H$ 
Ekstrak metanol dan etil asetat dibuat konsentrasi 100, 200, 300, 400, 500 $\mu \mathrm{g} / \mathrm{mL}$, dan ekstrak n-Heksan 200, 400, $600,800,1000 \mu \mathrm{g} / \mathrm{mL}$. Masing- masing konsentrasi ekstrak dipipet sebanyak 1 $\mathrm{mL}$, ditambahkan $1 \mathrm{~mL}$ larutan pereaksi DPPH, dicukupkan sampai $5 \mathrm{~mL}$ dengan metanol p.a pada labu ukur. Campuran dihomogenkan dan dibiarkan 30 menit, diukur dengan spektrofotometer UV-Vis pada panjang gelombang $515 \mathrm{~nm}$. Besarnya aktivitas antioksidan dihitung dengan rumus:

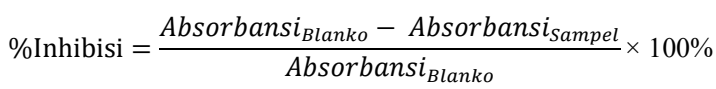

\section{Uji fitokimia (Harborne, 1987)}

a. Uji fenolik

Sebanyak $2 \mathrm{~mL}$ sampel ditambahkan 10 tetes $\mathbf{F e C l}_{3} \mathbf{1} \%$. Hasil positif ditandai dengan warna biru sampai biru kehitaman. b. Uji flavonoid

Sebanyak $2 \mathrm{~mL}$ sampel ditambahkan dengan $2 \mathrm{~mL}$ air panas, didihkan selama 5 menit, kemudian disaring. Filtrat sebanyak $5 \mathrm{~mL}$ ditambahkan $0,05 \mathrm{mg}$ serbuk $\mathrm{Mg}$ dan $1 \mathrm{~mL} \mathrm{HCl}$ pekat, kemudian dikocok kuat-kuat. Hasil positif ditandai dengan warna merah, kuning atau jingga.

\section{c. Uji terpenoid/steroid}

Sebanyak $2 \mathrm{~mL}$ masing-masing ekstrak ditambahkan $1 \mathrm{~mL}$ kloroform, ditambahkan 0,5 $\mathrm{mL}$ asam asetat anhidrat, ditambahkan $2 \mathrm{ml} \mathbf{H}_{\mathbf{2}} \mathbf{S O}_{\mathbf{4}}$. Hasil positif ditandai dengan terbentuknya cincin ungu pada perbatasan dua pelarut menunjukkan adanya triterpenoid, sedangkan jika terbentuk warna hijau kebiruan menunjukkan adanya steroid. Sedangkan jika berwarna merah menandakan terpenoid.

\section{d. Uji alkaloid}

Ekstrak dimasukkan dalam tabung reaksi, ditambah $0,5 \mathrm{~mL} \mathrm{HCl} 2 \%$ dan larutan dibagi dalam dua tabung. Tabung I ditambahkan 2-3 tetes reagen Dragendorff, tabung II ditambahkan 2-3 tetes reagen Mayer. Jika tabung I terbentuk endapan jingga dan pada tabung II terbentuk endapan

kekuning-kuningan, menunjukkan adanya alkaloid.

e. Uji saponin

Ekstrak dimasukkan dalam tabung reaksi ditambah air (1:1) sambil dikocok selama 1 menit, apabila menimbulkan busa ditambahkan $\mathrm{HCl} 1 \mathrm{~N}$, busa yang terbentuk dapat bertahan selama 10 menit dengan ketinggian 1-3 cm, maka ekstrak positif mengandung saponin.

\section{Hasil dan Pembahasan}

\section{Aktivitas antioksidan}

Dalam penelitian ini aktivitas antioksidan ditentukan dengan menggunakan metode DPPH. Metode uji aktivitas antioksidan dengan DPPH (2,2difenil-1-pikrilhidrazil) dipilih karena metode ini adalah metode sederhana, mudah, cepat dan peka (Molyneux, 2004). Aktivitas peredaman radikal bebas dapat dinyatakan dengan nilai $\mathrm{IC}_{50}$ (Inhibitory concentration), yaitu besarnya konsentrasi senyawa uji yang mengakibatkan hilangnya $50 \%$ aktivitas radikal bebas. Semakin kecil nilai $\mathrm{IC}_{50}$ maka semakin tinggi aktivitas antioksidannya. Nilai $\mathrm{IC}_{50}$ dapat ditentukan secara grafis menggunakan kurva kalibrasi dengan memplotkan konsentrasi ekstrak dengan \% inhibisi (Komala dkk., 2005). Nilai IC $_{50}$ untuk ekstrak dan pembanding vitamin $\mathrm{C}$ dapat dilihat pada Tabel 1.

Pada pengujian ini digunakan vitamin $\mathrm{C}$ sebagai kontrol pembanding, vitamin $\mathrm{C}$ memiliki gugus hidroksi bebas yang bertindak sebagai penangkap radikal bebas dan gugus polihidroksi yang dapat meningkatkan aktivitas antioksidan (Kim et al., 2005). Berdasarkan perhitungan diperoleh nilai $\mathrm{IC}_{50}$ vitamin $\mathrm{C}$ sebesar 1,72 $\mu \mathrm{g} / \mathrm{mL}$, aktivitas antioksidan vitamin $\mathrm{C}$ tergolong kategori sangat kuat dibandingkan dengan sampel yang ada. Aktivitas antioksidan ekstrak $S$. polycystum lebih tinggi dibandingkan ekstrak $T$. deccurens, dan ekstrak etil asetat memiliki nilai $\mathrm{IC}_{50}$ yang lebih tinggi dibandingkan ekstrak yang lain. Molyneux, (2004) menyatakan bahwa, 
nilai $\mathrm{IC}_{50}<50 \mu \mathrm{g} / \mathrm{mL}$ daya antioksidan sangat kuat, $\mathrm{IC}_{50} 50-100 \mu \mathrm{g} / \mathrm{mL}$ daya antioksidan kuat, IC $\mathrm{IC}_{50} 101-150 \mu \mathrm{g} / \mathrm{mL}$ daya antioksidan sedang dan $\mathrm{IC}_{50}>150$ $\mu \mathrm{g} / \mathrm{mL}$ lemah.

Tabel 1. Nilai $\mathrm{IC}_{50}$ ekstrak metanol, etil asetat, n-heksan dari Turbinaria deccurens dan Sargassum polycystum, serta kontrol vitamin $\mathrm{C}$

\begin{tabular}{ccc}
\hline Ekstrak & $\begin{array}{c}\text { Nilai } \\
\text { IC50 } \\
(\boldsymbol{\mu g} / \mathbf{m L})\end{array}$ & $\begin{array}{c}\text { Daya } \\
\text { Antioksidan }\end{array}$ \\
\hline $\begin{array}{c}\text { T. deccurens } \\
\text { Metanol }\end{array}$ & 340,06 & Lemah \\
Etil asetat & 180,54 & Lemah \\
n-Heksan & 502,25 & Lemah \\
S. polycystum & & \\
Metanol & 491,02 & Lemah \\
Etil asetat & 411,80 & Lemah \\
n-Heksan & 502,70 & Lemah \\
Kontrol & 1,72 & Sangat Kuat \\
Vitamin C & & \\
\hline
\end{tabular}

Aktivitas antioksidan ekstrak berhubungan dengan kandungan metabolit sekunder yang terkandung di dalamnya. Salah satu senyawa yang bertindak sebagai antioksidan yaitu flavonoid, yang merupakan kelompok fenolik terbesar yang secara luas terdapat pada tanaman. Berdasarkan Molyneux (2004), aktivitas antioksidan yang dihasilkan tergolong lemah, beberapa faktor yang dapat menyebabkan berkurangnnya aktivitas antioksidan yaitu flavonoid yang ada pada ekstrak kemungkinan masih merupakan flavonoid terglikosida, glikosida diketahui dapat menurunkan aktivitas antioksidan. Ekstrak juga dapat memberikan aktivitas yang lemah karena masih belum murni yang terdiri dari berbagai komponen senyawa (Sami, 2016). Faktor lain yaitu lebih dominannya metabolit sekunder steroid dan terpenoid pada alga coklat $T$. deccerens dan $S$. polycystum juga mempengaruhi hasil pengukuran dalam menghambat radikal DPPH.

\section{Skrining Fitokimia}

Uji fitokimia dilakukan untuk mengetahui kandungan metabolit sekunder suatu sampel. Hasil kandungan senyawa metabolit sekunder pada ekstrak metanol, etil asetat, dan n-heksana dari T. deccurens dan S. polycystum ditunjukkan pada Tabel 2.

Semua ekstrak mengandung golongan senyawa terpenoid dan steroid. Ekstrak $S$. polycystum tidak mengandung flavonoid dan saponin, sedangkan $T$. decurrens positif mengandung flavonoid pada ekstrak metanol dan etil asetat, serta saponin pada ekstrak metanol. Mekanisme antioksidan dalam meredam radikal DPPH dengan cara mendonorkan atom hidrogen. Sampel yang memiliki aktivitas antioksidan akan mereduksi DPPH menjadi DPPH-H (Molyneux, 2004).

Aktvitas antioksidan kedua sampel tergolong lemah. Hal ini terjadi karena senyawa-senyawa golongan terpenoid dan steroid tidak dapat mendonorkan atom hidrogen untuk meredam radikal DPPH. Sedangkan beberapa ekstrak yang mengandung golongan flavonoid tidak cukup banyak sehingga aktivitas antioksidannya lemah. 
Tabel 2. Hasil skrining fitokimia T.deccurens dan S. polycystum

\begin{tabular}{|c|c|c|c|c|c|c|}
\hline Ekstrak Sampel & Alkaloid & Flavonoid & Fenol & Saponin & Terpenoid & Steroid \\
\hline \multicolumn{7}{|l|}{ T. deccurens } \\
\hline Metanol & - & + & - & + & +++ & ++ \\
\hline Etil asetat & - & - & + & - & ++ & +++ \\
\hline n-Heksan & - & + & - & - & +++ & ++ \\
\hline \multicolumn{7}{|l|}{ S. polycystum } \\
\hline Metanol & - & - & + & - & + & +++ \\
\hline Etil asetat & - & - & ++ & - & + & +++ \\
\hline n-Heksan & - & - & - & - & + & +++ \\
\hline
\end{tabular}

Keterangan:

$++\quad$ : kandungan senyawa lebih banyak (warna sangat pekat)

$+\quad$ : mengandung senyawa (warna cukup pekat)

$+\quad$ : mengandung senyawa (sedikit berwarna)

- $\quad$ : tidak mengandung senyawa

\section{Kesimpulan}

Berdasarkan hasil penelitian yang dilakukan, dapat disimpulkan bahwa kandungan fitokimia ekstrak metanol $T$. deccurens yaitu flavonoid, saponin, terpenoid dan steroid. Ekstrak etil asetat mengandung senyawa fenolik, terpenoid dan steroid, sedangkan ekstrak n-heksan mengandung senyawa flavonoid, terpenoid dan steroid. Kandungan fitokimia yang terdapat pada ekstrak metanol $S$. polycystum yaitu fenolik, terpenoid, steroid. Ekstrak etil asetat

\section{Daftar Pustaka}

Bengen, D. G., 2001, Sinopsis Ekosistem dan Sumber Daya Alam Pesisir dan Laut. Pusat Kajian Sumber Daya Pesisir dan Lautan, Pusat Kajian Sumber Daya Pesisir dan Lautan, IPB, Bogor.

Budhiyanti, S. A., Raharjo, S., Marseno, D. W., and Lelana, I. Y. B., 2012, Antioxidant Activity of Brown Algae Sargassum Species Extract from The Coastline of Java Island, American Journal of Agricultural and Biological Sciences, 7 (3), 337-346. mengandung fenolik, terpenoid dan steroid, sedangkan ekstrak n-heksan mengandung terpenoid dan steroid. $S$. polycystum memiliki aktivitas antioksidan yang lemah untuk ekstrak metanol, etil asetat, dan $\mathrm{n}$-heksan dengan nilai $\mathrm{IC}_{50}$ 340,06, 180,54, dan 502,25 $\mu \mathrm{g} / \mathrm{mL}$ dan $T$. deccurens memiliki aktivitas antioksidan yang lemah dengan nilai IC $_{50}$ ekstrak metanol, etil asetat, dan n-heksan berturutturut $491,02,411,80$, dan $502,7 \mu \mathrm{g} / \mathrm{mL}$.

Harborne. J.B, 1987, Metode Fitokimia: Penuntun Cara Modern Menganalisis Tumbuhan (Diterjemahkan oleh Kokasih Padmawinta dan Iwang Soediro), Penerbit ITB, Bandung.

Kelman, D., Posner, E. K., McDermid, K. J., Tabandera, N. K., Wright, P. R., and Wright, A. D., 2012, Antioxidant Activity of Hawaiian Marine Algae, Marine Drugs, 10, 403-416.

Kim, J. S., 2005, Radical Scavenging Capacity and Antioxidant Activity of the $E$ vitamer Fraction in Rice Bran, Journal of Food Science, 70, 208-213 
Komala, I., Azrifitria, Y., Betha, O. S., Muliati, F., Ni'mah, M., 2015, Antioxidant and Anti-inflammatory Activity of The Indonesian Ferns Nephrolepis falcata and Pyrrosia lanceolata, International Journal of Pharmacy and Pharmaceutical Sciences, Vol 7, 12.

Molyneux, P., 2004, The Use of The Stable Free Radical Diphenylpicryl-hydrazil (DPPH) for Estimating Antioxidant Activity. Songklanakarin J. Science Technology, 26 (2), 211-219.

Permana, R. A., 2008, Karakteristik Serbuk Minuman Sari Buah Jeruk Lemon (Citrus medica var lemon) dengan Penambahan Na-alginat yang Diekstraksi dari Rumput Laut
Sargassum filipendula, Skripsi, Fakultas Perikanan dan Ilmu Kelautan, IPB, Bogor.

Sami, F. J., Rahimah, S., 2016, Uji Aktivitas Antioksidan Ekstrak Metanol Bunga Brokoli (Brassica Oleracea L. Var. Italica) dengan Metode Dpph (2,2 Diphenyl-1picrylhydrazyl) dan Metode Abts (2,2 Azinobis (3-etilbenzotiazolin)-6-asam Sulfonat), Jurnal Fitofarmaka Indonesia, 2 (2).

Yangthong, M., N., HutadilokTowatana, W., Phromkunthong, 2009, Antioxidant Activities of Four Edible Seaweeds from The Southern Coast of Thailand, Plant Foods Human Nutrition, 64, 218-223. 